\title{
The Murphy Murder Mystery: An Irish “Post-mortem Situation”
}

\author{
Scott Eric Hamilton \\ University College Dublin, Ireland
}

Copyright (c) 2021 by Scott Eric Hamilton. This text may be archived and redistributed both in electronic form and in hard copy, provided that the author and journal are properly cited and no fee is charged for access.

\begin{abstract}
This paper will propose that Beckett's affinity for crime and mystery fiction also contributes to Murphy. The novel will be examined on the proposed hypothesis that Murphy's death, so-called, is conspicuously left ambiguous to a certain degree, rendering it a type of mystery narrative. Approaching the mysterious death as something like a detective fiction "cold case", the events of Murphy, and clues left by Beckett throughout the prose that follows, I will investigate whether or not Murphy does actually die toward the end of the book. Although Beckett does not present these aspects in the traditional form of "thriller" fiction, he does use them to create a modernist aesthetic which challenges traditions, identifications of being, identity, representation and space regarding both the individual and the social context of the Irish "postmortem situation” depicted in Murphy.
\end{abstract}

Key Words. Samuel Beckett, “detective fiction”, Murphy.

Resumen. Este artículo propondrá que la afinidad de Beckett por el crimen y la ficción de misterio también forma parte de Murphy. La novela será examinada sobre la base de la hipótesis propuesta de que la muerte de Murphy, así llamada, se deja visiblemente ambigua hasta cierto punto, convirtiéndola en una especie de narrativa de misterio. Acercándome a la misteriosa muerte como algo así como un "caso sin resolver" de ficción detectivesca, los eventos de Murphy y las pistas dejadas por Beckett a lo largo de la prosa posterior, investigaré si Murphy realmente muere o no hacia el final del libro. Aunque Beckett no presenta estos aspectos en la forma tradicional del género del “thriller”, sí los utiliza para crear una estética modernista que desafía las tradiciones, las identificaciones del ser, la identidad, la representación y el espacio con respecto al contexto individual y social de la "situación post-mórtem" irlandesa representada en Murphy.

Palabras clave. Samuel Beckett, “ficción detectivesca”, Murphy. 
For those familiar with Beckett's 1938 novel Murphy, the fact that Murphy dies in an explosion is perhaps a forgone conclusion. Considered testament to Murphy's fate, in a 1936 letter to Thomas McGreevy, Beckett states, "I have set Murphy on fire at last \& 2000 words should polish it off" (2009b, 337, sic). Suppose, however, the "Murphy" to which Beckett refers is the novel, the it of "2000 words should polish it off" (2009a, 337, emphasis added) and not the protagonist. Analysing the published text exclusively through Beckett's "Grey Canon" is of course potentially reductive. Nonetheless, the proposed (perhaps over-pedantic) reading of Beckett's statement emphasises the ambiguity of the novel. Murphy exudes considerable ambiguity surrounding the events leading to the identification of the corpse as Murphy, which presupposes the following premise: Murphy does not die in the explosion.

However, the above premise is not entirely convincing. As counterproductive as this may seem, the statement identifies the difficulty of analysing the ambiguity of the events in Murphy. Posing such a questionable premise foregrounds both Murphy's enigmatic "death" and the nefarious Magdalene Mental Mercyseat (MMM) “explosion”. Without definitive evidence, establishing Murphy's “death” is largely circumstantial ensuring the mystery persists despite efforts to the contrary. The ambiguities and inaccuracies function to promote potential misreadings of the events throughout the novel so that neither Murphy's death can be established as empirical truth - regardless if accepted or rejected. Thus, Murphy is, at least in part, an unsolved murder mystery. The following will demonstrate how questioning established interpretations is a valuable exercise, even if to reaffirm the validity of those interpretations. The empirical world of pre-modernist and early modernist detective fiction finds itself, in Beckett's late-modernist novel at least, in its own "post-mortem situation". This article will argue that Murphy, as a type of murder mystery, confronts empirical categorisations of notions such as truth, justice, facts, and logic as inherently fallible on account of the subjective nature of individual perception and self-serving motivation.

Discrepancies surrounding Murphy's “death” have garnered ancillary attention in Beckett studies, primarily by Rubin Rabinovitz (1984) and C.J. Ackerley (2010). For instance, Ackerley contests Rabinovitz's suggestion that Cooper is the culprit: not being employed at the MMM, Cooper would not have access to Murphy's room nor the chain to the gas valve (207). Such contentions validate John Bolin assertion that Murphy "has long been dividing its readers" (771). Nonetheless, Murphy as a constructed "murder mystery" has not exactly been of primary analytical concern. For example, the novel has been examined predominantly in regard to archival, psychoanalytical, philosophical, or historical frameworks. Considering certain shared commonalities and divergences with elements of detective fiction, the inability to prove conclusively that an explosion results in the death of the protagonist, establishes Murphy, at its core, as an unsolved murder mystery and subsequently an anti-detective story. Henri Lefebvre maintains that "ambiguity is a category of everyday life, and perhaps an essential category" (18). As such, Murphy adopts the ambiguity of everyday mundane modern existence into its aesthetic form. Revisiting the intricacies of the traditional detective story will not be performed here, except where applicable: nonetheless, the ambiguity surrounding Murphy's presumed death situates the novel in vague relation to the anti-detective genre, without conforming to genre conventions.

Beckett's prose continually eludes rigid categorisation. For instance, James McNaughton explains Beckett's form of late modernism is a "restless pitting of one interpretation against the other in the service of evaluating modernism's contradictions" (6). Relatedly, Shane Weller indicates that Beckett's canon reflects aspects of late modernism, including inauthenticity and collapsing distinctions of ideology and genre. He argues that, as a result, Beckett's late modernist texts, reverberating the "anti-generic impulse of the literary avant-garde," remain elusive to inclusion in either modernism or postmodernism: 
Given [his] commitment to a form, style and language that would serve, in their radical originality, to capture "how it is", together with the abiding sense that this struggle is futile, Beckett's postwar oeuvre might more accurately be located within neither high modernism nor postmodernism, but rather within (for Beckett, appropriately liminal and belated) space which has come to be known as late modernism. $(2015,91)$

Murphy indeed occupies that liminal and belated space between modernism and postmodernism, detective and anti-detective fiction. Weller continues: "If the presentation of the human body as mechanical or puppetlike is a late modernist trait, then few writers exhibit this more forcefully than Beckett” (93). Of course, Weller's assessments of the novel are accurate: Murphy is a late modernist novel in that the human bodies presented therein are either "mechanical or puppetlike"; however, Murphy the non-puppet, then, is neither late modern nor postmodern. The former unable to die and the latter denied arrival reflect in the radical futility of Beckett's work. Hence, the desire for an unobtainable post-mortem situation present through Beckett's canon. Consequently, Murphy is an experiment in "post(mortem)-modernism" (that is, an aesthetic which neither allows modernism to die nor accepts the arrival of postmodernism). Although admittedly "tongue-in-cheek", the post(mortem)-modernism designation emphasises the futility of engaging with Murphy through any singular conceptual or generic framework (like detective fiction for example). Consequently, Murphy, as late modernist text, presents a murder mystery that reflects the uncertainties of stable meaning of the interwar era: the stable, but perhaps restrictive, ideologies of law, order, and justice promoted by detective fiction had become destabilised by metaphysical, and metafictional, ambiguity which eventually contributes to the postmodern project.

Murphy as a late modern parody of detective fiction expresses anticipatory tendencies of postmodernism. Michael Holquist argues that for postmodern metaphysical detective fiction, "[t]he most common expectation, based on reading classical detective fiction, which PostModernism defeats is that of syllogistic order", and that "Post-Modernists use as a foil the assumption of detective fiction that the mind can solve all: by twisting the details just the opposite becomes the case” (155). Perhaps as a precursor to postmodern metaphysical detective fiction, Beckett's late modernist tendencies not only twist the details but obfuscates their purpose almost entirely. As a result, the narrator presents a world languishing in varying states of subjective inaccuracy, benign irrationality, and mundane disorder. Murphy, as a murder mystery, then, stages the philosophical and psychoanalytical parody of the supremacy of the logical mind though scientific misinformation, logical inaccuracies, and syllogistic breakdowns. Belated and anticipatory, Murphy could be described as an experiment in literary Post-mortemism: portraying ambiguous existence after the death of absolute meaning and representation.

Claiming Beckett belongs to any one genre would of course be erroneous. Similar to Smith's point that Watt and Molloy parody borrow from and parody the detective genre (300), Murphy may contain trace elements of traditional detective fiction but the mundane disorder therein dispels inclusion into the genre. James Knowlson offers a description of Molloy equally applicable to Murphy:

clues lead nowhere; plans appear aimless and go significantly awry; [...] events lack importance, at least in terms of plot; [...] Sir Arthur Conan Doyle, whose stories Beckett loved as a boy, would have shuddered at a world so impervious to reason and deductive logic. (372)

The world of Sherlock Holmes, indeed, appears governed by deductive reason and logic supporting an overarching ideological order under to which any threat is dispelled by the moral 
and intellectual prowess of the detective. Conversely, in the pseudo-postcolonial Irish world of Murphy, especially the Irish citizens in London, cause and consequence is fraught with unresolvable mystery and perpetual ambiguity. The Irish troupe in London may be surrounded by a system of law and order but they do not seem to have the ability, nor the desire, to access that system. J.C.C. Mays, in the Murphy prelude, notes it is "evident that the organisation of the particulars is upset by a number of deliberate contradictions and loose ends" (xvii). With copious "loose ends," the comical inconsistencies and contradictions negate any opportunity to resolve the mystery in Murphy and suggest a perpetually inconsistent world void of any uniform ideological governance.

Beckett's affinity for detective fiction, including - but not exclusively - Arthur Conan Doyle, has been explored mostly in relation to Watt, Molloy, and Malone Dies. For example, Frederick N. Smith relates Watt to the Sherlock Holmes tales; Philip Howard Solomon claims the "second half of [Molloy] is narrated by a sort of private detective, Moran" (10); likewise, Julie Campbell argues that the Moran character in Molloy is a parody of the secret agent figure; and, Melvin J. Friedman identifies both Moran and Malone as detective-like figures. Unlike its successors, Murphy contains no readily identifiable elements of tradition detective fiction, namely the detective figure. Nonetheless, Murphy displays elements of a murder mystery which positions it as the first in the series that follow. Writing to George Reavey, Beckett states he is about to finish "Malone Meurt, the last I hope of the series Murphy, Watt, Mercier \& Camier, Molloy” (Letters V. II, 80). Excluding More Pricks Than Kicks, in which the protagonist indeed dies, the series beginning with Murphy - which later includes The Unnamable - have central characters that, regardless of claims desiring otherwise, remain alive at the conclusion of their narratives. Therefore, Murphy dying explicitly would be uncharacteristic of the series. Beckett's protagonists are wandering, elusive figures that avoid being detected, and qualified, in any substantial way. This elusiveness reflects, to a certain degree, Todd Herzog's claim that the "criminals that initially seem to be the objects of investigation are rarely the most important figures" (41) standing opposed to the social critique presented. As such, Beckett, in positioning Murphy as the object of the informal investigation of Neary and company, dismantles the traditional structure by situating the "criminal" as the primary figure of importance. However, Murphy, as far as can be discerned, is not a criminal, which means no legitimate detective is required. Although, as Katherine Ebury notes, Murphy's horoscope recommends he become a detective (143), Murphy lacking a criminal or a detective is the antithesis of the detective procedural story because ideological structures of truth and justice are destabilised in the resent postcolonial Irish context.

William Spanos posits "Watt and Molloy (especially the Moran section)" (154, sic) exemplify postmodern anti-detective fiction, which frustrates the objective of traditional detective narratives. Spanos explains how the procedural narratives

demand the kind of social and political organization that finds its fulfilment in the imposed certainties of the well-made world [...]. It is therefore no accident that the paradigmatic archetype of the postmodern imagination is the anti-detective story (and its psychoanalytical analogue), the formal purpose of which is to invoke the impulse to "detect" [...] in order to violently frustrate it by refusing to solve the crime. (ibid)

Beckett definitely mocks any "impulse to 'detect"' by opposing the "certainties of the wellmade world" (ibid) by presenting potentially unsolvable mysteries, sometimes even including possible murder, imbued with insurmountable ambiguity and contradictions of logic. For example, in Molloy, Moran faces the question of the ambiguous "Molloy affair" (106), and while seeking the answer he commits murder of an unidentified individual, yet both situations 
remain unsolved. Murphy as a murder mystery indicates a debt to detective fiction of the entire series it initiates.

The potentially unsolvable mystery in Murphy is further evidence of its place in the series of novels. Relative to the detective fiction genre, the plot trajectory from Ireland to England mimics how the few Irish Detective writers of the early twentieth century set their work in England. Spanos explains anti-detective stories "drive the [solid citizen] out of the fictitious well-made world, [...] to be exposed to the existential realm of history, where Nothing is certain" (67). The Irish characters of these novels, and Murphy as well, lack an Irish detective to provide resolution according to nationalistic ideologies like their English counterparts. ${ }^{1}$ Ireland as not entirely post-colonial - by remaining part of the British commonwealth - and not entirely established in its own national identity, reverberates in Murphy with the dual locations of Ireland (Dublin) and England (London). Murphy presents a near oppressive presence of police (An Garda Siochána) in Dublin as opposed to a complete absence of police (Metropolitan Police) in London. Both locations portray Irish citizens not governed by stable, or even coherent, structures of judicial process. Therefore, the Beckett novels associated with aspects of detective fiction are also anti-detective stories on account of the ideological ambiguity and lack of any substantial resolution they experience. In Murphy solving crime and obtaining any traditional sense of justice is clearly not a priority; consequently, the lacklustre facade of resolution contests the infallibility of the institution of justice that was so prevalent in the prewar era that would become so severely inadequate after the horrors of one world war and on the precipice of another.

The ability to uphold ideological constructs in detective fiction is precipitated by either a mystery, usually a missing person, or a perplexing murder. Carl D. Malmgren explains that "murder initiates the mystery novel, and the novel is at pains to reconstruct the events leading up to that murder" (18). The threat to perceptions of order and safety of a potentially unsolved murder to begin the story is eased by the inherent promise that the logical and moral detective will dispel that threat without fail. The typical detective story opening suggests an unchangeable universal system posing only the pretension of a potentially unsolvable mystery eventually dispelled by the astute intellectual. Foreshadowing his ability to dispel the looming threat, Sherlock Holmes proclaims a uniform lack of mystery in A Study in Scarlet: "There is nothing new under the sun. It has all been done before" (30). ${ }^{2}$ This Holmesian mantra, and biblical reference (Ackerley, 28), reverberates as parodic cliché in the opening of Murphy presenting a uniformly mundane, world: "The sun shone, having no alternative, on the nothing new" (1). The Doyle-like phrase is a pretext for the perpetual mundane existence of the entire novel and not a statement proclaiming the inevitability of resolution for the mystery. Beckett undoes tradition by placing the murder at the conclusion of the story. With this inversion, Beckett exposes the false pretence of a world maintained through sound logic and reason in which any mystery will eventually be resolved. The normalised uncertainty in Murphy further frustrates the impulse to detect by disallowing the possible resolution for even the mundane mysteries of everyday life. The insurmountable ambiguity of Murphy challenges the ideological constructs of empirical truth and order that traditional detective narratives attempt to represent and uphold. In the world Beckett creates truth claims are exposed as inadequate performances of abject language.

Ackerley claims the ironic opening of Murphy is "suggestive of a Victorian mystery perhaps Conan Doyle's A Study in Scarlet, with its 'scarlet threat of murder running through the colourless skein of life'” (59). Similarly, the narrator of More Pricks references Doyle's infamous detective directly: "The old man was gradually settling down, it did not require a Sherlock Holmes to realise that" (180). Detective fiction emphasises early in the narrative the rudimentary reasoning skills needed by the detective to dispel trivial conundrums. This aspect conditions the anticipation of more perplexing events which require sophisticated deductive 
reasoning to solve any given mystery; the capacity for deductive reasoning establishes the authority of the detective so that any subsequent performed feats of logic will be accepted without question. In contrast, no such authority exists in Murphy. The other characters lack deductive reasoning skills which renders declarations of Murphy's death untenable: honesty is in short supply in the world of Murphy. After all, Beckett indicates to McGreevy that Murphy is "not very honest work" (2009b, 337). Beckett's remark, intentionally or not, emphasises the dishonesty of the narrator of Murphy. The impossibility of the opening statement of section three, "The moon [...] was 29,000 miles nearer the earth than it had been in four years" (19), exemplifies the narrative dishonesty throughout the text, which brings many of the details being accurate into question. This narrative dishonesty exposes the potential dishonesty of the Conan Doyle generic convention that poses a mystery that has already been solved before the narrator presents the tale.

Detective novels present a mystery, often involving death or missing persons, for which the cunning detective must ascertain the truth in the pursuit of justice. For Neary and his accomplices, Murphy fulfils the role of the missing person: although he is not missing from the narrative of the novel, he is missing from the narrative of their Irish context. Not considering Murphy or the death of Celia's parents, Murphy contains two such mysterious deaths which hint at this tradition. ${ }^{3}$ In the morgue scene, the reference to Neary's wife as being, "Not strictly speaking [...] his [Neary's] wife” (40) is another questionable detail delegitimising the accuracy of information provided. Ariadne Neary née Cox is revealed by Cooper when he discreetly "whispered that the Cox was dead" (170). The narrator explains that she "swallowed 110 aspirin following the breaking off of a friendship with a Mr. Sacha Few, an anti-vivisection worker" (170). The reason for the Cox ingesting a lethal dose of aspirin and how it relates to Mr. Few the anti-vivisection worker remains unanswered. The anti-vivisection movement of the late nineteenth century and early twentieth century, promoted conducting experiments on human subjects in place of animals subject and were often conducted at asylums and hospitals across London. Perhaps not so coincidentally, the National Anti-Vivisection Hospital in Battersea was located in the area of London where Murphy partly takes place. Regardless of historical accuracy, the death of the Cox leaves another unexamined clue rendering its significance ambiguous and another death unresolved. With this ambiguous clue, Beckett offers a disingenuous gesture to the Victorian gothic by leaving the reference unsubstantiated, denying the gothic tradition any direct influence. Beckett's texts may indeed be informed by various literary traditions but they are in no way governed by those traditions.

The other mysterious death is that of the old boy in Miss Carridge's house. Knowlson notes that this scene was inspired by real-life events experienced by Beckett while in London and that he "uses the event [of death] to play with conventional narrative technique and to weave an elaborate set of circumstances around it” (206). The elaborate, and often haphazardly conveyed, circumstances eschew overt markers of a potential murder mystery surrounding the deaths in the novel. Knowlson indicates this scene exemplifies the way Murphy "parodies the deductive logic of the Conan Doyle stories” (206). The scenario shares peculiar details with Edgar Allen Poe's Murders of Rue Morgue, in which a woman is killed by a razor in her rented accommodation. The physician in Poe's story concludes, “The throat had been evidently cut with some sharp instrument - probably with a razor" (17). Whereas, in Murphy, Miss Carridge claims the old boy suffers a seizure and "falls on his face with the razor under him, zzzeeeppp!" (Murphy, 91-2). The narrator explicitly indicates her claims are "Lies [...] All lies" (91-2), but without a detective to prove otherwise her lies remain unchallenged and the potentially mysterious death of the old boy remains unsolved. Consequently, the salacious, and perhaps fallacious, reasoning by Celia that "to owe Miss Carridge rent would be a dreadful situation" (92) suggests the old boy's outstanding rent was paid with his life. In Poe's story the reason behind the murder revealed by detective Dupin (a belligerent orangutan being the culprit) is as 
absurd as Miss Carridge's account of the death of the old boy is believable. This is not to suggest Miss Carridge murdered the old boy, but the circumstances are nefarious nonetheless. The suspicious, and heinous, circumstances of the old boy are quickly discarded, however, suggesting that the only order needed restoring is the quickest possible return to the mundane. Miss Carridge, as a pun on 'miscarriage' (Cohn 74), indicates how such situations in Beckett where the excitement of a mysterious become miscarriages of detective fiction convention.

Regarding detective novels, Ernst Bloch notes that "[b]efore the first word of the first chapter something has happened, but no one knows what, apparently not even the narrator. [...] The obscure deed is not even presented in a prelude, for it is as yet unpresentable, except through the process of reconstruction from investigation and evidence" (37). The following story provides all the potential clues needed for a cunning investigator. Bloch indicates that "a crime, usually murder, precedes the beginning" (ibid) of the detective novel. However, the opening of Murphy indicates nothing significant has happened prior to the first sentence of the novel. With the potential murder occurring toward the end of the novel, Murphy stands as the prelude to a detective novel which is never given the opportunity to occur. The detective story which should follow is, presumably, never provided, which accounts for the ambiguous details, unreconstructed events, and lack of resolution for the identifiable deaths in the novel. As a murder mystery without resolution, Murphy initiates the futile impulse to detect in the following series of detective-like figures with no real mystery to resolve.

Although Beckett inverts the standard mystery narrative by positioning the murder toward the end of the novel, Murphy, retaining some elements of tradition, employs duplicity in both its construction and its place in the canon. ${ }^{4}$ Murphy as the second of Beckett's early prose works exploits the overt death of Belacqua in More Pricks to promote the illusion of commonality aligning the suggested death of Murphy to his predecessor. Unlike Belacqua's explicit death in More Pricks, the narrator of Murphy only implies a similar fate: "Soon his body would be quiet, soon he would be free" (158). This sentence, widely accepted as verification of Murphy's death, provides no ostensible evidence, especially considering the same sentence resides in the opening section. The vague claim does not confirm the death of Murphy in the first section and doing so in the twelfth section, even if ironically, confounds verification with implication. The repetitious implicit phrase, "soon his body would be quiet, soon he would be free" $(8,158)$ is one of numerous textual allusions to an impending death which distracts from questioning whether or not the corpse is Murphy. With the mystery deemphasised, and lack of resolution subverted, the suggestion of Murphy's death becomes the primary focus which exploits perception as unstable, subjective and easily influenced destabilising notions of order based on reason and logic.

The Neary cohort all have motive for not contesting Murphy as the deceased. Early in the novel, Neary indicates he would gladly accept "a legal attested certificate of [Murphy's] demise" (36) because "as Murphy is even a remote possibility Miss Counihan will not parley" (41). Neary's motive for Murphy pronounced deceased would apparently satisfy this condition by Miss Counihan: Wylie and Cooper would be paid and released from service; and, Miss Counihan (also paid) and Celia would be free of their romantic attachment to Murphy. Nonetheless, the conspiring puppets (including Dr. Killiecrankie, also paid by Neary) seem content accepting the unconvincing illusion of Murphy's death to restore their temporarily disordered worlds which Murphy unwittingly causes. Therefore, the narrator's claim that in the morgue Bim and Ticklepenny "paused in the passage to collect Murphy" (162) should not be accepted unquestionably. Relatedly, the claim that "the body, mind and soul of Murphy were freely distributed over the floor of the saloon” (171) may be accurate, but the perpetual textual inaccuracies and inconsistencies undermine the validity of such statements.

The evidence for Murphy's “death” is uniformly circumstantial resulting in the unreliable identification of the body in the morgue. When Murphy and Ticklepenny first meet 
the narrator indicates a lack of precision of medical practices in the asylum that a "rumour of misdiagnosis began to raise its horrid head in the M.M.M.” (57). As a form of misdirection, another potential misdiagnosis "raise[s] its horrid head" in the morgue scene. On account, Neary accepts unequivocally the corpse as Murphy. The narrator, possibly misrepresenting Neary's reaction, states “Neary saw Clonmachnois on the slab, the castle of the O'Melaghlins, meadow, eskers, thatch on white, [...] Connaught" (167). Neary's perception is uncharacteristic as Murphy is anything but representative of such romanticised Irish elements. Nonetheless, Neary's erroneous romanticisation of the body would invalidate his identification, which he does not actually provide.

Conversely, Celia identifies the body according to a supposed birthmark: "The remains having been turned over, Celia addressed herself with a suddenly confident air to the further charred buttocks and found at once what she sought. [...] "Here he had a big birthmark"” (166). Celia's identification of the birthmark on the "charred buttocks" is questionable. Earlier when she finds Murphy naked tied to his overturned chair the narrator reports: "A huge pink nævus on the pinnacle of the right buttock held her spellbound. She could not understand how she had never noticed it before” (20). Either she had never seen Murphy naked before (unlikely given their relationship), she had simply never noticed the mark (unlikely given her reaction), the mark evolved very recently (possible), or she is being disingenuous (perhaps the most probable); nonetheless, the inaccurate accounts of the mark alone exclude it as positive identification. Nevertheless, this circumstantial evidence is accepted as definitive proof because each member of the group, for their own reasons, wants to believe the corpse represents Murphy's death.

Although the coroner corroborates Celia's claim, "A proper port-winer [...] the afterglow is unmistakable" (166), he has also proven himself highly unreliable in his observations. He, who would rather be playing golf, states the "remains [...] were deposited just within my county, my county” (162), which presumably includes the MMM morgue. If the remains were Murphy, he would have undoubtedly died already residing in the county over which the coroner presumably presides making his statement nonsensical. Even if the MMM is based on Bethlehem Royal Hospital, which straddled a county line, splitting the jurisdiction of a hospital makes little sense. Moreover, the coroner admits his knowledge of "physiology is rather rusty" (163) further devaluing his medical authority. Performances of corroboration, like the coroner's, can influence pre-conceived notions of reality as much as factual evidence, or the lack thereof.

Dr. Killiecrankie, marginally less unreliable, describes the supposed identifying mark as "an extensive capillary angioma of the most unusual situation" (166). According to the medical field of the late 1930s, birthmarks are usually classed as cavernous angiomas whereas the capillary angioma is usually a tumorous growth and are rare (Geschickter and Keasby, 5702). A capillary angioma, and especially one "of the most unusual situation", is suggestive of a tumor which could discredit Celia's recognition of a birthmark. An angioma, or "pink nævus" (20), can occur at birth but can dissolve with age: such marks lasting throughout a lifetime is uncommon. Whether Killiecrankie means the tumorous or benign angioma, or is generally mistaken, is unclear. However, such angiomas - also called hemangioma - are described as port-wine stains, hence the coroner's response. Nonetheless, the lack of specificity regarding angioma type undermines the accuracy of both claims. In the world of Murphy, much like the actual world, even "expert opinions" are prone to subjective bias - or self-interest - as much as factual evidence.

Non-expert opinions are even less reliable. Miss Counihan states emphatically the cadaver is not Murphy: “'I knew of no such mark,' she cried, 'I don't believe he ever had a horrid mark like that, I don’t believe it's my Murphy at all, it doesn't look at all like him, I don't believe"” (166). This contradicts her earlier claim upon first seeing the corpse: "This is 
Murphy, whose very dear friend I was" (165). Therefore, the conflicting statements render the visual identification of the body being inconclusive. Nevertheless, along with Killiecrankie's assertion that Murphy's numerous marks (mental, physical, moral, spiritual, and functional) are "Remarkable for their pertinacity, [...] with which they elude the closest autopsy" (165), the body being severely burned renders the chance of a superficial dermal mark surviving unlikely, further discrediting the farcical visual identification of the remains.

In literature and film, the act of producing a will intends to convey the associated individual is indeed deceased. Similarly, the dubious production of Murphy's "will” is another diversionary tactic. Rabinovitz suggests that the will being addressed to "Mrs. Murphy" draws its authenticity into question, as Celia and Murphy are not married $(1984,114) .{ }^{5}$ Miss Carridge is the first to refer, perhaps ironically, to Celia as "Mrs. Murphy” $(140$, sic) when Wylie inquires if Murphy is in residence. Wylie, knowing the address and assuming Celia and Murphy were married, could have produced the potentially falsified will and then provided it to Killiecrankie. Miss Counihan inquires unsuccessfully when the will was dated in an attempt to discredit its validity. Ackerley argues this detail "ensures the mystery of the will is finally unresolvable" (210) and Shoshana Benjamin equally refutes the legitimacy of the document (122). Despite how Killiecrankie obtained the document, or who produced it, being unclear, the legitimacy of the will is actually irrelevant in preference for the narrative result: the presumption of Murphy's death. Rabinovitz posits that "[i]t seems unlikely that the will would have survived after an explosion that left Murphy's body completely charred and no trace of the horoscope" (1984, 115). Additionally, emphasis is placed on Murphy keeping the horoscope with him: "Many times he had taken it out to destroy it. Lest it fell into the hands of his enemy” (49). Indeed, as Killiecrankie claims, if Murphy "had any other papers, they were consoomed" (161, sic). Neary's desire for a quick resolution is motive to expedite the unanimous acceptance of Murphy's death, which the will facilitates. ${ }^{6}$ Everyone, as a result, misreads the burned corpse for their own purposes. All these distracting details are intended for the mystery to be overlooked too easily.

The possibility of Murphy's "death" as suicide, being implied in the text, is often disregarded by scholars as unlikely. Likewise, Beckett expresses his own uncertainty of suicide as a possibility in a 1951 letter: "I don’t think Murphy can have committed suicide, in the material circumstances, but the possibility can't be ruled out. In any case he was already dead, as a result of mental suicide. Such is my humble opinion” (Letters V. II, 247). Rabinovitz asserts "Murphy's last wish [...] was not to commit suicide but to return to Celia" $(1984,116)$; likewise, Benjamin postulates: "Suicide is ruled out by Murphy's intent to return to Celia and is technically unfeasible as well" (122). Indeed, Murphy, after a "short rock" in his chair, intended to "dress and go, before the day staff were about, [...] back to Brewery Road, to Celia" (157). Earlier, outside the Royal Free Hospital, the narrator claims Murphy considers a "postmortem situation, its advantages were present in such detail to his mind, that he actually hoped he might live to be old” (51). The lack of commentary for the days between his last shift and the morgue further promotes the assumption that Murphy died in an explosion. An astute detective would undoubtedly perform a feat of deductive logic confirming the identity of the body. Beckett's anti-detective novel, though, provides no such performance, leaving only the fallible perception of resolution.

Suspicious behaviour from the other characters further promotes potential foul play. For instance, Wylie's actions prior to the morgue scene seem nefarious. This wiliness, which his name suggests, remains from "the Murphy Notebooks" which, although redacted, provides evidence of Beckett considering Wylie committing two potential murders (UoRMS5517/3/191). Although Wylie's murderous intent is omitted in the published novel, while in the hotel the group has a cryptic discussion about no longer needing Murphy to resolve their absurd romantic entanglement. Wylie then takes Neary's check-book and leaves 
promising to resolve the issue. Possessing Neary's check-book, Wylie could have procured the corpse, ensured the coroner would verify the identity, and produced the unsigned will addressed to "Mrs. Murphy [...] in Brewery Road" (161). The next day Neary states, "life does not seem so precious" (139) before deciding to wait for Murphy in Brewery Road. During his absence Wylie could, hypothetically, have made arrangements for the staging of Murphy's death. Once in Brewery Road, the Neary gang strangely intern themselves with Celia in Miss Carridge's house for "two days and three nights" (160) waiting for Murphy to return, suggesting the need to establish an alibi for sinister purposes. Even if that purpose is to simply stage Murphy's death.

Staging Murphy's death, though, does not account for the lack of evidence of an explosion resulting nor the origin of the corpse "deposited" in the morgue. Generating any conclusive statements regarding the identity of the body, other than Murphy would, only produce speculations with varying degrees of plausibility. Nevertheless, excluding those present in the morgue, Mr. Endon is a somewhat plausible option to be the corpse. He has demonstrated the propensity to wander the halls and is drawn to switching lights on and off. A preoccupation with switches is reasonable on account of Endon's near blindness resulting from Graves' disease. Mentioned in Murphy's horoscope, Graves' Disease is a type of hyperthyroidism classified by Irish physician Robert Graves. In extreme cases Graves’ Disease causes almost complete blindness except for the ability to differentiate between light and dark. Furthermore, the disease can cause protracted eyelids making the eyes appear unusually larger. Although, traditionally associated with metaphysical issues, a possible analytical misdiagnosis, Endon clearly exhibits symptoms of Graves' disease: "For the whites, of which a sliver appeared below the upper lid, were very large indeed and the pupils prodigiously dilated, as though by permanent excess of light. The iris was reduced to a thin glaucous rim: (Murphy, 155). Having escaped again, accidentally opened the gas valve, entered Murphy's room, and inadvertently caused the explosion, Endon is a plausible, but highly improbable, proxy for the charred remains misidentified as Murphy.

However, one subtle detail substantially significantly undermines establishing the identity corpse conclusively: the narrative never explicitly indicates that a gas explosion occurs in the MMM. Subtle allusions to gas, fire, explosions, and disfigurement promote the assumption that the radiator installed in Murphy's room by Ticklepenny caused a catastrophe. For example: after presenting letters "calculated to annoy" Celia she possessed from Murphy, "Miss Counihan brought her letters together with the sound of a sharp faint explosion" (144, emphasis added); following the morgue scene Mr. Kelly is described as "his blue eyes blazed in the depths of their sockets [...] for he burned with excitement" (172, emphasis added); and, "The gas went on in the w.c., excellent gas, superfine chaos" (158, emphasis added). These allusions, and numerous others, only gesture toward a tragic demise promoting the conclusion that an explosion actually occurred; however, the actuality of the event is only implied but not explicitly stated. Concluding that an explosion did occur which caused Murphy's death would be a presumptive projection of meaning which lacks substantiation.

Regardless of the degree of plausibility, providing a viable alternative identity for the corpse remains improbable; therefore, the unidentified victim is quickly cremated, fated to perpetual anonymity. As Murphy lacks a detective to extrapolate meaning and reason from anonymity, the resulting destabilisation of order exemplifies Beckett's confrontation with modes of representation extends to the intended ethical realism of detective fiction. In this sense, the mystery supplements other aspects of the novel. For example, Shane Weller, regarding pre-Socratic nihilism in Beckett, argues that "ethical nihilism in Beckett finds expression not as the belief that every "opinion" is "equally false" [...], or that there can be no determination of value at all, but rather in the value that is assigned to the "naught"” (2008, 330). Therefore, the Neary cohort only require a plausible "naught" to which their idea of 
Murphy can be assigned, which the unidentifiable burned corpse provides. Weller highlights Beckett's debt to "Geulincx's "Ubi nihil vales, obi nihil velis" (Where you are worth nothing, there you should wish for nothing)" (326). In other words, when an individual has no value in a place, that place offers nothing of value to the individual. The featureless cadaver, then, provides the group a way to perceive the negation of Murphy's value. Hence the callous treatment by Cooper of scattering the remains on the dirty of a nameless pub. Whether the ashes are him or not, Murphy, like many Irish migrants of the era, dissolved one way or another into a type of exile. The value of place dissolves, and Murphy becomes the catalyst for Beckett's series of failed detectives relegated to a post-mortem situation of meaningless wandering.

Murphy, the first post-mortem figure, wanders in silent proximity to other Beckett texts. As such, The Murphy mystery is proliferated through a series of reported "sightings" from Mercier and Camier into the later prose suggesting the possibility of Murphy being alive. Echoing the unidentified pub where Cooper deposited the ashes, Mercier, in an undisclosed pub, remarks to Watt, "I knew a poor man named Murphy [...] he died ten years ago, in rather mysterious circumstances. They never found the body, can you imagine”: to this Watt responds "my dream" (111). Watt's nihilistic dream of becoming naught is denied by his appearance in Mercier and Camier in relation to the novel which bears his name. Mercier's claim simultaneously supports the assumption of Murphy's death and the possibility of his mysterious disappearance. Malone alludes to the unresolved deaths in Murphy when asking himself "How many have I killed, hitting them on the head or setting fire to them? Off-hand I can only think of four, all unknowns [...] There was the old butler too, in London I think [...] I cut his throat with a razor" (Malone Dies, 237). Two of these unknowns could be the man Moran kills and the burned cadaver in Murphy; whereas, referring to cutting the throat of the "old butler" in London, Malone seems to claim responsibility for the old boy's death. The Unnamable claims “All these Murphys, Molloys, and Malones don't fool me” (305). Murphy, and his continued wandering, appears as late as the short prose Fizzles (1973-5): "Murphy had first-rate legs" (225). These allusions provide no substantial evidence, however, which perpetuates the frustrated impulse to detect through the series. The post-mortemism of Murphy exemplifies the way naught, in Beckett's canon at least, is a present silence with value unbeholden to place.

Detective fiction utilises distracting excessive details and extraneous lines of reasoning to provide the illusion of a well-ordered world. However, Beckett simultaneously acknowledges and subverts this literary tradition in Murphy which poses a subtly disordered world resulting from the inability of those within it to employ deductive reasoning to explain the ambiguous circumstances surrounding the protagonist. Antoine Dechêne argues that "Beckett's novel [Molloy] never stops playing with the fundamental ambiguity that determines the grotesque and the abject, the former working as an ongoing tension between the horrifying and the comical while the latter is a result of simple horror" (220). The dubious evidence implies both the probability and improbability of Murphy's gruesome demise. Nonetheless, the truly grotesque aspect of the morgue scene is the way the group inadequately applies language to the horrific scene they witness. The comically absurd use of logic allows the character to dismiss confronting the true horror that potentially lays beneath their own notions of identity, an unidentifiable and grotesque self. As a post-mortem traditional detective fiction, Murphy dispels any claims to "Truth," empirical or otherwise, as an abjection of language. The improbable "Truth" of existence is an imposition of abject meaning, one which Murphy attempts to escape. Dechêne posits that in Molloy, that for Moran "true meaning can only be found in silence" (242). Of all Beckett's creatures, Murphy is perhaps the only one that obtains an existence of silence and therefore escapes the improbability of "truth".

In conclusion, this article will undoubtedly receive divided responses. However, Andre Furlani notes that in Beckett's work "[a]mbiguity is an aberration that solicits interpretation" (451). Consequently, objections to the murder mystery premise will function, and perhaps 
convincingly, to re-confirm already established interpretations. Whereas accepting the unresolved mystery premise could result in re-evaluating the novel to produce new interpretations that both contradict and complement traditional interpretations. Nonetheless, the inability to prove either demonstrates how Murphy exposes the "frail partition between the illconceived and the ill-revealed, the clumsily false and the unavoidably so" (161). To conclude, yet again, if empirical truth in the late modern era inhabits a postmortem situation, the enigma of Murphy's mysterious circumstances will continue enticing the impulse to investigate the ambiguous world of Murphy; however, nothing is certain.

\section{Notes}

${ }^{1}$ Elizabeth Mannion indicates Irish detective fiction authors exclusively aimed their work at the English market by setting their narratives in England (5-8).

2 Ackerley offers another possible influence for this statement (29).

${ }^{3}$ Agatha Christie also has a character named Celia, Unfinished Portrait (1934), whose parents died mysteriously, like Beckett's Celia whose parents perished on “the ill fated Morro Castle” (Murphy, 10)

${ }^{4}$ See Rabinovitz (1984) for the duplicitous aspects of the novel.

${ }^{5}$ Rabinovitz examines the narrator's unreliability (1984, 104-5).

${ }^{6}$ Ackerley provides alternative readings of the will enigma (297).

\section{Works cited}

Ackerley, C.J. Demented Particulars: The Annotated Murphy. Edinburgh: Edinburgh University Press, 2010.

Beckett, Samuel. "Murphy Notebooks" UoR MS5517. Reading: Beckett International Foundation, University of Reading. More Pricks Than Kicks. London: Calder, 1993.

The Complete Short Prose: 1929-1989. Ed. S.E. Gontarski. New York: Grove Press, 1995.

Mercier and Camier. London: Calder, 1999 (1974).

. Trilogy: Molloy, Malone Dies, The Unnamable. London: Calder, 2003 (1995).

Murphy. Ed. J.C.C. Mays, London: Faber, 2009a.

The Letters of Samuel Beckett Volume I. 1929-1940. Ed. Martha Dow Fehensfeld and Lois More Overbeck, Cambridge: Cambridge University Press, 2009b.

The Letters of Samuel Beckett Volume II. 1941-1956. Eds. George Craig, Martha Dow Fehensfeld, Dan Gunn, and Lois More Overbeck, Cambridge: Cambridge University Press, 2011.

Benjamin, Shoshana. “Seen and Unseen in Beckett's Cryptic Novel Murphy.” Narrative 28. 1 (2020): 103-24.

Bloch, Ernst. “A Philosophical View of the Detective Novel.” Discourse 2 (1980): 32-52.

Bolin, John. "Beckett's Murphy, Gide's Les Caves du Vatican, and the "Modern” Novel." Modernism/Modernity 18. 4 (2011): 771-88.

Campbell, Julie. “Moran as Secret Agent.” Samuel Beckett Today/Aujourd'hui 12 (2002): 8192.

Cohn, Ruby. A Beckett Canon. Ann Arbor: University of Michigan Press, 2005.

Conan Doyle, Arthur. Sherlock Holmes: The Novels, New York: Penguin Books, 2015.

Dechêne, Antoine. Detective Fiction and the Problem of Knowledge: Perspectives on the Metacognitive Mystery Tale, Houndmills: Palgrave Macmillan, 2018.

Ebury, Katherine. Modernism and Cosmology: Absurd Lights. Houndmills: Palgrave Macmillan, 2014. 
Friedman, Melvin J.. “The Neglect of Time: France’s Novel of the Fifties,” Books Abroad 36. 2 (1962): 125-130.

Furlani, Andre. “The Contradictions of Samuel Beckett.” Modernism/Modernity 22. 3 (2015): 449-70.

Geschickter, Charles F., and Louisa E. Keasbey. “Tumors of Blood Vessels.” The American Journal of Cancer 23. 3 (1935): 568-91.

Herzog, Todd. "Crime Stories: Criminal, Society, and the Modernist Case Study." Representations 80. 1 (2002): 34-61.

Holquist, Michael. "Whodunit and Other Questions: Metaphysical Detective Stories in PostWar Fiction.” New Literary History 3. 1 (1971): 135-156.

Knowlson, James. Damned to Fame: The Life of Samuel Beckett. London: Bloomsbury, 1997.

Lefebvre, Henri. Critique of Everyday Life Volume 1, translated by John Moore, London: Verso, 2008 (1991).

Mannion, Elizabeth. "A Path to Emerald Noir: The Rise of the Irish Detective Novel.” The Contemporary Irish Detective Novel. Ed. Elizabeth Mannion, London: Palgrave Macmillan, 2016: 1-16.

McNaughton, James. Samuel Beckett and the Politics of Aftermath. Oxford: Oxford University Press, 2018.

Malmgren, Carl Darryl. The Anatomy of Murder: Mystery, Detective and Crime Fiction. Bowling Green: Bowling Green State University Popular Press, 2001.

Poe, Edgar Allen. The Murders in the Rue Morgue and Other Stories. New York: Reader's League of New York, 1940.

Rabinovitz, Rubin. The Development of Samuel Beckett's Fiction. Urbana: University of Illinois Press, 1984.

"Murphy and the Uses of Repetition." On Beckett: Essays and Criticism. Ed S.E. Gontarski. New York: Grove Press, 1986: 67-90.

Smith, Frederick. "Watt, Watson, and Sherlock Holmes: As Detective Fiction." Samuel Beckett Today/Aujourd'hui 16 (2006): 299-317.

Solomon, Philip Howard. “Samuel Beckett’s Molloy: A Dog's Life.” The French Review 41. 1 (1967): 84-91.

Spanos, William V. "The Detective and the Boundary: Some Notes on the Postmodern Literary Imagination.” Boundary 2, 1.11 (1972): 147-68.

Weller, Shane. "Beckett and Late Modernism.” The New Cambridge Companion to Samuel Beckett. Ed. Dirk Van Hulle, Cambridge: Cambridge University Press, 2015: 89-102.

"“Gnawing to be Naught”: Beckett and Pre-Socratic Nihilism." Samuel Beckett Today/Aujourd'hui 20 (2008): 321-33.

Received: 19 November 2019

Revised version accepted: 17 June 2020

Scott Eric Hamilton is a research associate at the UCD Humanities Institute and a lecturer for the UCD School of English, Drama, and Film and a writing instructor in the UCD Writing Centre. Hamilton has published in various journals on Samuel Beckett and other topics. He has co-organised a successful series of international conferences entitled "Beckett and the 'State' of Ireland” (2001-2013), “Palimpsests: V International Flann O’Brien Conference” (2019), and “Theorizing Zombiism” (2019). He has co-edited a volume of essays from both the "Theorizing 
Zombiism" conference and the "Flann O’Brien" conference as well as guest edited a special issue of The Parish Review: Journal of the International Flann O'Brien Society.

scott.hamilton@ucd.ie 